\title{
Evolutionary positioning of outsourcing in the local public administration
}

\author{
Carles López (iD), Salvador Linares (iD), Josep Viñas (iD) \\ Universitat de Girona (Spain) \\ clopez@dartem.cat,salvador.linares@udg.edu,josep.vinas@udg.edu
}

Received August, 2018

Accepted March, 2019

\begin{abstract}
Purpose: This work intends to establish a new methodology to quantitatively measure the initial position and evolution of outsourcing in a public administration.

Design/methodology: Product of the generalization of a methodological tool based on the fuzzy set theory "index of maximum and minimum level," a method is designed to evaluate the evolution of the positioning of outsourcing in a public administration.
\end{abstract}

Findings: The proposed model that is presented opens up the possibility to study the evolution of public administration in terms of the actions that have been taken to reach an ideal outsourcing position, which would allow managers to create points of control at various stages to ensure the success of the actions taken.

Research limitations/implications: The limitations to the proposed method are directly related to the cases established in the fuzzy set theory. As an example, having to choose a specific value for the ideal values in an outsourcing strategy implies a regression to the concept of certainty. The work shows no examples of how to overcome these problems, although it does offer some ideas on how to minimize them.

Practical implications: This work offers a tool to help determine the degree to which the objectives have been reached that are established within a public administration with regard to actions associated with outsourcing.

Social implications: The ability to establish a distance from an ideal value means that citizens can numerically analyze whether the actions taken by the management team have improved or worsened the position of the public administration in terms of its outsourcing actions.

Originality/value: The work offers two original proposals. First, it offers an expansion of an index customarily used to calculate the distance from an ideal position. Second, it offers a context in which to demonstrate the usefulness of the index.

Keywords: Outsourcing, Fuzzy sets, Measurement, Public management, Local administration

Jel Codes: B41, C02, C65, H41, H44, H72 


\section{To cite this article:}

López, C., Linares, S., \& Viñas, J. (2019). Evolutionary positioning of outsourcing in the local public administration. Intangible Capital, 15(2), 157-170. https://doi.org/10.3926/ic.1352

\section{Introduction}

Outsourcing has been the response by the private sector to the needs of companies to deal with the current constantly changing competitive environment (White \& James, 2000). The scenario usually requires companies to generate greater flexibility and adaptability in order to reduce fixed costs and to focus their efforts and resources on those processes in which they are specialists. Therefore, the aim of this management tool is for an entity outside a particular organization to take responsibility for performing one or more services on its behalf.

New Public Management, commonly known by the initials NPM (Montesinos \& Gimeno, 1998) seeks to improve efficiency, effectiveness and transparency as key elements for decision-making (Christensen, 2006). This interest has arisen primarily as the result of the financial crisis and the problems with budget management experienced by many public administrations (Lodge \& Hood, 2012).

Therefore, given that public officials are looking for tools to help them improve the management of the services they provide, and taking into account that outsourcing has been a management tool proven by private companies to be capable of providing greater flexibility, greater adaptation to changes, cost reduction and/or restructuring and a focusing of efforts on those products and/or services in which the organization specializes (Savas, 2000), accepting that the public administration has options in order to outsource (Mas, 2000), in this work, we try to analyze certain matters related to outsourcing in the local public administration.

Furthermore, some authors (Van Slyke, 2003; Johnston \& Girth, 2012) argue that the use of these "market" tools increase transaction costs, i.e., that implementing control systems in order to certify that outsourcing generates efficiency and efficacy can prove to be too expensive.

In addition, great competition among service providers can create pressure on production costs and thus trigger a drop in transaction costs (Johansson, 2008). In turn, if a sort of oligopoly exists among the service providers, they are aware of the difficulty in replacing them and, one way or another, they increase the transaction costs (Brown \& Potoski, 2004).

However, in order to decide on the activities that are suitable for being outsourced, an internal analysis must be carried out of the organization, establishing clear strategic objectives and evaluating the capacities and resources the organization has to achieve the objectives with maximum possible efficiency and efficacy (Espino \& Padrón, 2004). Based on this analysis, the activities, processes and areas of the company must be chosen that are not essential to it, that provide little or no added value or those in which the company is not specialized and has no interest in doing so.

It should be explained that the outsourcing of public services consists of transferring to an external organization, through the refinement of a certain contract model, but without this means transferring the responsibility of the service to the external entity in any case (Mas, 2004). Consequently, the service continues to be a public responsibility, as does its planning, control and evaluation, and as a result, in no case can it be considered that this constitutes a situation of privatization of the public service (De los Mozos, 2003).

The present work intends to create a tool to evaluate the degree of compliance with the outsourcing objectives set by the public administration. Using this tool, the public management would have a quantitative instrument capable of improving the degree of fulfillment of the objectives set in the outsourced public services.

In order to achieve the above goal, the work begins with a section analyzing outsourcing in the public sector. Following this, a section is presented on vague statements and the fuzzy set theory (Zadeh, 1965), the 
methodological basis for the mathematical tool. The next section will present in detail the mathematical tool "the generalized index of maximum and minimum level." Finally, an application of the possibilities the tool has will be shown in a specific case, based on a classification of the mandatory and non-mandatory services that a town council must provide. The work ends with the conclusions and bibliography sections.

\section{Analysis of outsourcing in the public sector}

Of the different theoretical approaches to organizational decision-making, if we focus on organizational theory (Mouzelis, 1989), we will realize that its relationship with the public administrations has been rather complicated. This has been even truer in recent years, as the latter have taken on new functions and objectives that have triggered important changes in their composition and structure.

First of all, we have to assess whether the theoretical conceptions of organizations can apply to such a specific area as the public administration. While it is true that all organizations are basically identical in terms of their elements, characteristics and problems, on occasion certain insurmountable differences appear. In this sense, public organizations have needs that are similar to those of organizations in the private sector with regard to attaining their objectives in an effective, efficient manner, which is why it is accepted that their more operational areas can benefit from the knowledge and tools related to organizational theory.

Nevertheless, there are certain elements that mark the public administration as a different type of organization, such as the fact that public entities do not choose the environment in which they act, rather this is defined by regulations, while the private sector positions itself wherever it sees the possibility for profit or expansion. Likewise, the environment surrounding public management is much more complex, which increases the needs for negotiation, and governmental organizations are more vulnerable to the pressures of a political nature in short-term electoral conflicts. Furthermore, the management of human resources in the public sector is much more conditional, in terms of both the selection and the promotion or exclusion of its staff members, making it very difficult to reward the excellence of managers. Other underlying aspects of the public administration are the degree of control, the lack of flexibility in the management of financial resources and the absence of the sensation of risk. Therefore, there are elements to justify the public administration as a different sort of organization, although to implement certain management mechanisms from private enterprise, there must be a separation between the political level and the technical level.

If we wish to apply a tool such as outsourcing to a specific sector like the public administrations, we must analyze how it has functioned in the private sector (White \& James, 2000), since it is here where the first steps were taken.

However, before considering subcontracting any of the functions to external companies, it is necessary to think about and answer certain questions in order to know what outsourcing needs an organization has. In fact, outsourcing does not make sense if the objectives can be met using internal resources (Viñas, 2012).

The first step towards decision making is to clearly define the objectives, evaluating the internal options and, if appropriate, the suitability of having external partners, with the idea of obtaining a reference for achieving the planned benefits, i.e., setting objectives that make sense and that can be measured. However, the process for setting objectives is more difficult than it would seem, because many times it becomes an imprecise task. In order to avoid this, we must define management indicators (Brusca, 1997), detect the needs of future users, evaluate the influence of these on the required change and analyze the technological innovations needed to develop it.

Once the objectives have been clearly established, the own potential must be evaluated, i.e., calculating what the maximum theoretical capacities are that our current structure can utilize, assuming the different internal limitations. If this theoretical potential is insufficient to meet the company's objectives, we can contemplate the purchase of outside resources as an alternative to our internal restrictions.

Once the internal situation of the administration is analyzed, we must focus on what the generic reasons are for outsourcing the services. First of all, there is a matter related to the fixity of the costs, in other words, the possibility of converting some of the fixed costs into variable costs, primarily in reference to staffing costs, and 
the reduction of investments and inventories. Secondly, increasing the flexibility of the organization, prioritizing the areas in which it is more effective and changing the priorities according to market conditions, may also be a goal. Furthermore, we can consider improving the efficiency of the public entity, achieving faster time cycles that improve the organization's performance and that are more permeable to innovative ideas. Finally, there is gaining access to new markets and service opportunities through the supplier network (Girth et al., 2012), expanding operations without the need for extraordinary financing.

Outsourcing is applicable to all processes or areas of the organization where resources are consumed without contributing any added value. They generally consist of activities that make intensive use of current expenses, that form part of specialized or support services, that are subject to an excessively changing market with difficulties to recruit employees or that, for technological reasons, require a large investment.

When an organization decides to resort to outsourcing, it must consider what criteria it will use for this purpose and what the consequences will be. Therefore, if an organization outsources due to a lack of resources and capacities in certain areas, the need to concentrate on the main activities or the existence of unimportant factors that can be acquired in the market, the size and structure of the organization is normally reduced.

Consequently, we must analyze which are essential resources and which do not contribute any specific value to the organization. According to this, any valuable or irreplaceable factor constitutes an asset that is too specific to be contracted outside the organization, while the factors that are more efficient in the market must be acquired in it.

In this sense, an organization should invest in those factors that constitute basic competences, i.e., those that permit it to obtain a long-term competitive edge that is normally achieved through group learning. These competences are directly related to the users' needs and the organization must perform them better that its competitors.

For this reason, outsourcing, from the perspective of basic competences, permits the organization to focus on innovation, eliminating the inflexibility of fixed resources and improving its knowledge by taking advantage of the experience of its suppliers. Therefore, those activities that do not provide a suitable result in terms of cost or performance must be outsourced outside the company (Santolaria, 2004). Likewise, in the area of processes, performing certain activities within the administration in which it is not necessary to differentiate the organization in order to obtain a competitive advantage can have very high production costs, which is yet another reason to outsource them.

In summary, we can cite the words of Professor Argyres (1996) when he proposes that "organizations will vertically integrate those activities in which they have more experience and organizational skills than their suppliers and outsource those others in which they have lesser capacities, except in those cases where they have decided to accept high costs over the short term, while the capacities are being developed."

However, in the decision-making process regarding outsourcing in the public sector, areas suitable for outsourcing will be identified, excluding those that clearly need direct management and justifying the technical criteria for those that can be managed indirectly.

On the one hand, the functions excluded from outsourcing will be those that depend primarily on political decisions, i.e., in which the ideological criterion takes precedence over the technical aspect, and those that generate the discretionary exercise of authority, i.e., those functions that, in legal terms, imply imperium (Sosa, 1992). One example would be the local police service, which has an important strategic value and likewise implies the exercise of authority.

On the other hand, once the non-outsourceable functions have been defined, we must differentiate between the functions that are generically outsourceable, where we find those that are intensive in terms of low-skilled human resources, those that are highly specialized, those subject to fluctuating workloads and those that are finalist, such as waste collection, and functions that are subjectively outsourceable, in other words, that need a subsequent analysis for their assessment, such as in the case of environmental protection. Accordingly, in this 
latter typology, there is an entire series of factors that must be analyzed. First of all, there is the strategic value, where the contribution of the function to the overall added value of the service is evaluated. In these terms, the lower the added value is, the greater the possibilities are of outsourcing. Secondly, there is the prevision of the evolution of its functions, with a special analysis of future demand, in such a way that greater demand results in less outsourcing. Thirdly, the stability of markets and resources must be considered, in the sense that a market that needs certain resources with very fast technological changes will involve functions that are good candidates for being outsourced. Finally, there are economic conditions, i.e., the competitiveness of the market and the transaction costs, in such a way that a high level of competitiveness and low costs will lead to outsourcing (White \& James, 2000).

Once the organization decides on what activities it wants to outsource, it is very important to have a good system to evaluate and control these outsourced public services. For this reason, we think it is appropriate to consider their design. As some authors propose (Mas, 2000), we must develop a system for monitoring the outsourcing based on different considerations. First of all, to design a good monitoring system, it is necessary to define the basic variables we wish to review (quality, efficacy, efficiency, etc.) regardless of the type of service we are going to analyze. Secondly, specific indicators must be established for each service that will allow us to verify the status of each of the control variables that have been chosen, as well as to define the values that the indicators must reach in order to consider that the service meets the desired expectations. Thirdly, the methodology must be determined that will be used to collect all of the above information during the service provision and how often this control is to be performed, without eliminating the possibility of random controls. Finally, the supervisory team must be designated, as well as the design of the activities it must perform during the service provision.

In order to better analyze the processes of the different services, it is necessary to know the real situation of the town councils, according to current regulations on the local administration in Catalonia, and thus be able to evaluate the different typologies we can encounter.

First of all, within the area of competences, the town councils can, in the management of their interests, promote activities and public services to meet the needs of the citizens. According to the Law establishing the Bases for Local Government (LBRL), we can consider a series of issues to be the competences of the municipalities, such as urban development, the environment, social services, public transport, leisure, tourism, culture, sports, education, etc. In any case, based on these competences, according to the LBRL, the local governments must provide a series of services, according to the population of each. We will attempt to summarize these below.

All local governments must arrange to provide services related to public lighting, cemeteries, waste collection, street cleaning, domestic drinking water supply, sewer systems, access to population centers and the paving of public roads. In addition, towns with a population of more than 5,000 residents must also see to providing services related to public parks, libraries, markets and waste treatment. Likewise, towns with a population of more than 20,000 residents must also provide civil defense services, the evaluation and information about situations of social needs or risk of exclusion, fire prevention and fire fighting, as well as sports facilities for public use. Finally, towns with a population greater than 50,000 residents must also provide services related to urban public transport and protection of the urban environment.

The rest of the services will be considered non-mandatory services, but even so, they are incredibly important in the management of a local administration. According to the studies conducted in recent years (Mas \& Vilalta, 2011), the non-mandatory expenditure of the town councils in Catalonia represent more than a third of the total municipal expenditure. This non-mandatory expenditure is, to a large extent, a current expenditure and consists fundamentally of expenses related to employee remuneration, although the purchase of goods and services can also have a considerable weight. From a functional perspective, of particular importance are the areas of culture, public safety, education and housing, with aspects such as health care and transportation relegated to a secondary level.

Therefore, taking into account the previous characteristics, we could divide the services that can be outsourced into 4 groups. As part of a preliminary analysis, we will include some examples of each type. 
a) Mandatory services related to the maintenance of the municipality and infrastructures

a1. Waste collection

a2. Street cleaning

a3. Waste treatment

a4. Paving of public roads

b) Mandatory services related to global attention to people

b1. Social services

b2. Public library

b3. Public transportation

b4. Sports facilities

c) Non-mandatory services related to the maintenance of the municipality and infrastructures

c1. Promotion of housing rehabilitation

c2. Health and safety in public spaces

c3. Tourism

c4. Archives

d) Non-mandatory services related to global attention to people

d1. Child care

d2. Museums

d3. Theaters

d4. Children's leisure

At this point, we realize that we must analyze the current situation of outsourcing in the local administration, since we have observed that there is not enough academic doctrine that establishes what the objectives are of outsourcing. For this reason, and since we will need to use quantitative aspects, it seems appropriate to propose tools related to the fuzzy subset theory, which we will discuss below.

\section{Fuzzy subset theory}

Deciding whether an object meets a certain property can be perfectly possible with certain statements, such as "less than 25 years old" or "owns an automobile." These types of statements are known as crisp statements. However, there are statements like "is intelligent" or "is kind", in which this classification can generate serious doubts in this regard. This type of statements is known as vague statements (Russell, 1923).

Similarly, there are statements that cannot be classified as true or false (Lukasiewicz, 1920; Black, 1937). Aristotle (De interpretatione, Chapt. IX) offered the opinion, for example, that the declarative statement "There will be a sea battle tomorrow" cannot be considered either true or false. His reasoning can be summarized as follows: if the statement at the time it was spoken is true, nothing can prevent a naval battle from occurring tomorrow. If it is false, the same thing occurs, in other words, there is no way for a naval battle to occur tomorrow. Therefore accepting that at the time it is pronounced, the statement is either true or false would mean that our future has always been and always will be predetermined, and according to Aristotle, this does not make sense, since in general, future events have the possibility of occurring or not occurring. 
With the emergence of the fuzzy subset theory (Zadeh, 1965), a linguistic context was created with which to lay the foundations for problem solving under a new logical paradigm in which the value of the truth of a statement or the degree to which an object belongs to a set was not identified with yes or no values (Trillas, Alsina \& Terricabras, 1995; Lazzari, Machado \& Pérez, 2012). In this new paradigm, it is possible to state the value with which an object in a set meets a property with a specific value of between $0 \%$ and $100 \%$.

Figure 1 shows one way of visualizing this idea. The figure forms a set made up of 884 squares that symbolize the objects in a set. Each square is painted in a shade somewhere between black and white, symbolizing the degree to which each object meets a certain property. The fact that the figure contains gray indicates that this subset cannot be considered as a classic subset of the reference set, since there could only be black and white colors, symbolizing that either the object meets a certain property or does not meet it.

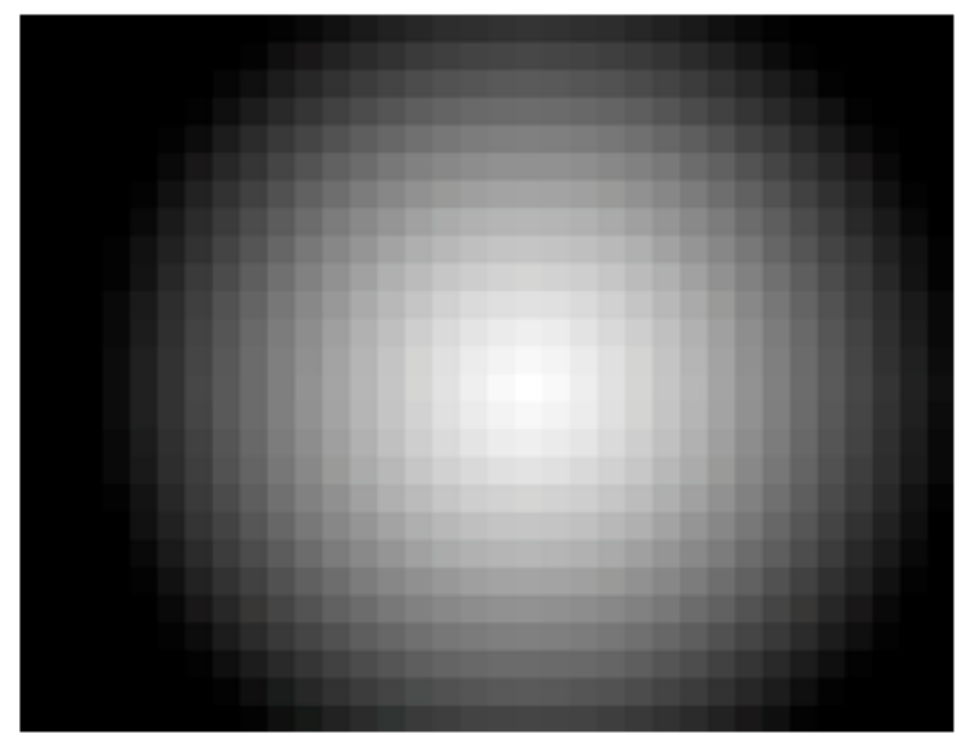

Figure 1. Fuzzy subset (created with Adobe Photoshop)

The acceptance of the fundamentals of the fuzzy subset theory allows us to find better solutions to general problems more simply for the same type of modeling (Linares-Mustarós, Ferrer-Comalat \& Cassú-Serra, 2013; Linares-Mustarós, Merigó \& Ferrer-Comalat, 2015; Linares-Mustarós, Ferrer-Comalat, Corominas-Coll \& Merigó,2019; Ferrer-Comalat, Linares-Mustarós \& Corominas-Coll, 2016, 2018; Corominas, Ferrer-Comalat, Linares-Mustarós \& Bertran, 2017), and to create new techniques that are currently used in various industrial applications, such as control systems used to focus video cameras or for vehicle brakes (Terán et al., 1987; Kaufmann \& Gupta, 1988).

Currently, the number of works that use fuzzy principles number in the tens of thousands, and the exponential growth of publications related to this topic leads us to think that there is still a long way to go with this topic.

The following section presents a tool that uses the fuzzy principles of the new theory. The tool will be the basis upon which we can establish a distance from an outsourcing position to the ideal outsourcing position.

\section{Generalized index of maximum and minimum level}

The index of maximum and minimum level (Gil-Lafuente, 2001) is based on a seminal proposal for solving a personnel selection problem by Gil-Aluja and Kaufmann (1986). These authors used a distance between fuzzy subsets, which was designated as the Hamming distance, which makes it possible to obtain a numeric value that symbolized the idea of deviation between these two subsets.

Specifically, they defined the following distance function, in which $\mathrm{X}$ is the set $[0,1] \mathrm{x}^{\mathrm{n}-2} \mathrm{x}[0,1]$. 
$\mathrm{d}: \quad \mathrm{XxX} \quad \rightarrow \quad \mathrm{R}$

$$
\begin{aligned}
& \left(\mathrm{x}_{1}, \mathrm{x}_{2}, \ldots, \mathrm{x}_{\mathrm{n}}\right) \mathrm{x}\left(\mathrm{y}_{1}, \mathrm{y}_{2}, \ldots, \mathrm{y}_{\mathrm{n}}\right) \rightarrow \sum_{\mathrm{i}=1}^{\mathrm{n}}\left|\mathrm{x}_{\mathrm{i}}-\mathrm{y}_{\mathrm{i}}\right|= \\
& =\left|x_{1}-y_{1}\right|+\left|x_{2}-y_{2}\right|+\cdots+\left|x_{n}-y_{n}\right|,
\end{aligned}
$$

As an example, if the characteristics sought in an employee were friendliness, good appearance and hard-work, and it is decided that the ideal worker is one who meets the first characteristic to a degree of 0.7 , the second characteristic to a degree of 0.8 and the third characteristic to a degree of 1 , given two candidates with scores of 0.6, 0.5 and 0.7, and 0.9, 0.8 and 0.6, respectively, the distance would produce deviation results of 0.7 for the first candidate and 0.6 for the second. As a result, it was suggested that the second candidate should be the candidate selected for the job position, since he had the least deviation from the ideal values (the mentioned works by the authors and the works applying the tool to the selection of personnel and athletes by Gil-Aluja (1996) and Grado (2006) contain excellent examples to consolidate the tool. Since later we will discuss semi-distances, it is necessary to know that a semi-distance is a definite application in such a way that it meets all the distance properties except the P4-b property).

It is easy to demonstrate that the application proposed by the authors was a distance, as it met the following properties:

P1. Non-negativity

$$
\mathrm{d}(\mathrm{x}, \mathrm{y}) \geq 0 \quad \forall \mathrm{x}, \mathrm{y} \in \mathrm{X}
$$

P2. Symmetry property

$$
\mathrm{d}(\mathrm{x}, \mathrm{y})=\mathrm{d}(\mathrm{y}, \mathrm{x}) \quad \forall \mathrm{x}, \mathrm{y} \in \mathrm{X}
$$

P3. Triangular inequality property

$$
\mathrm{d}(\mathrm{x}, \mathrm{y}) \leq \mathrm{d}(\mathrm{x}, \mathrm{z})+\mathrm{d}(\mathrm{z}, \mathrm{y}) \quad \forall \mathrm{x}, \mathrm{y}, \mathrm{z} \in \mathrm{X}
$$

P4. Identity property

$$
\mathrm{d}(\mathrm{x}, \mathrm{y})=0 \leftrightarrow \mathrm{x}=\mathrm{y} \quad \forall \mathrm{x}, \mathrm{y} \in \mathrm{X}
$$

Note: The identity property can at the same time be seen as the sum of the following two properties (since later we will discuss semi-distances, it is necessary to know that a semi-distance is a definite application in such a way that it meets all the distance properties except the P4-b property):

P4-a. $\quad \mathrm{d}(\mathrm{x}, \mathrm{x})=0 \quad \forall \mathrm{x} \in \mathrm{X}$

P4-b. If there are two elements $\mathrm{x}, \mathrm{y} \in \mathrm{X}$ in such a way that $\mathrm{d}(\mathrm{x}, \mathrm{y})=0$, then $\mathrm{x}=\mathrm{y}$.

In order to solve similar problems, taking into account that the qualities could have a different relative importance, the same authors proposed in later works introducing the possibility of assigning different weights in the formula, creating what they called the weighted Hamming distance:

$$
\begin{array}{cccc}
\mathrm{d}: & \mathrm{Xx} \mathrm{x} & \mathrm{R} \\
\left(\mathrm{x}_{1}, \mathrm{x}_{2}, \ldots, \mathrm{x}_{\mathrm{n}}\right) \times \quad\left(\mathrm{y}_{1}, \mathrm{y}_{2}, \ldots, \mathrm{y}\right) \rightarrow & \sum_{i=1}^{n} w_{i}\left|x_{i}-y_{i}\right|= \\
& & =\mathrm{w}_{1}\left|\mathrm{x}_{1}-\mathrm{y}_{1}\right|+\mathrm{w}_{2}\left|\mathrm{x}_{2}-\mathrm{y}_{2}\right|+\cdots+\mathrm{w}_{\mathrm{n}}\left|\mathrm{x}_{\mathrm{n}}-\mathrm{y}_{\mathrm{n}}\right|,
\end{array}
$$

Where $\mathrm{w}_{\mathrm{i}}$ is the weight assigned a priori to each quality, fulfilling the equality $\sum_{\mathrm{i}=1}^{\mathrm{n}} \mathrm{w}_{\mathrm{i}}=1$ 
The maximum and minimum level coefficient stems from the observation by Gil Lafuente (2001) that the idea by Kaufmann and Gil Aluja penalized both persons who did not reach the required level and those who had levels above the required level.

In the search for a possible solution, the author, based on a ranking of the characteristics in which the first $\mathrm{k}$ ones are penalized for both an excess and a deficit and the next $s$ are penalized only for a deficit, provided the following formula for creating an index that could penalize excesses or deficits with regard to an ideal value, or only deficits:

$I($ ideal, $x)=\sum_{i=1}^{k} w_{i} \mid$ ideal $_{i}-x_{i}\left|+\sum_{i=k+1}^{k+s} w_{i}\right| \max \left(0 ;\right.$ ideal $\left._{i}-x_{i}\right) \mid$

Given that on certain occasions, it might also be interesting to penalize only excesses, an index is presented below that expands the previous index and also permits establishing the parameter for $\mathrm{m}$ characteristics in which we wish to penalize only excesses.

The formulation of the new index is based on an arrangement of the characteristics in which in the first $\mathrm{k}$ characteristics both the excess and deficit are penalized; for the next s characteristics, only a deficit is penalized; and in the last $\mathrm{m}$ characteristics, only an excess is penalized.

The general mathematical formula is:

$$
I_{g}(\text { ideal }, \mathrm{x})=\frac{1}{k+s+m}\left(\begin{array}{c}
\sum_{\mathrm{i}=1}^{\mathrm{k}} \mathrm{w}_{\mathrm{i}} \cdot \mid \text { ideal }_{\mathrm{i}}-\mathrm{x}_{\mathrm{i}} \mid+\sum_{\mathrm{i}=\mathrm{k}+1}^{\mathrm{k}+\mathrm{s}} \mathrm{w}_{\mathrm{i}} \cdot \max \left(0 ; \text { ideal }_{\mathrm{i}}-\mathrm{x}_{\mathrm{i}}\right) \\
+\sum_{\mathrm{i}=\mathrm{k}+\mathrm{s}+1}^{\mathrm{k}+\mathrm{s}+\mathrm{m}} \mathrm{w}_{\mathrm{i}} \cdot \max \left(0 ; \mathrm{x}_{\mathrm{i}}-\text { ideal }_{\mathrm{i}}\right)
\end{array}\right)
$$

It is interesting to observe that the generalized index uses the Hamming distance and two semi-distances to obtain a numerical value of between 0 and 1 that makes it possible to have an idea of the degree of deviation between a certain position and the ideal position. Values closer to zero represent better approximations to the ideal position.

Below is a simple mathematical numerical example with a single characteristic of each type. In other words, we have three characteristics for which it is necessary to penalize both the excess and the deficit for the first characteristic, only penalize the deficit for the second characteristic and penalize only the excess for the third characteristic. Therefore, the calculation of the index is based on the observation that $\mathrm{k}=1, \mathrm{~s}=1$ and $\mathrm{m}=1$.

Let's assume that the ideal degrees of satisfaction with regard to outsourcing are those shown in Table 1.

\begin{tabular}{|l|r|}
\cline { 2 - 2 } \multicolumn{1}{c|}{} & Ideal situation \\
\hline Characteristic 1 & 0.6 \\
\hline Characteristic 2 & 0.8 \\
\hline Characteristic 3 & 0.2 \\
\hline
\end{tabular}

Table 1. Ideal values

The ideal degrees, along with the penalization criterion, can be symbolized using Table 2 .

\begin{tabular}{|l|l|l|}
\cline { 2 - 3 } \multicolumn{1}{c|}{} & Ideal situation & Penalization criteria \\
\hline Char. 1 & 0.6 & penalizes $\neq$ \\
\hline Char. 2 & 0.8 & penalizes < \\
\hline Char. 3 & 0.2 & penalizes $>$ \\
\hline
\end{tabular}

Table 2. Ideal values with penalization criteria 
Finally, we use Table 3, which expands Table 2, showing the relative importance weights considered for each characteristic, the ideal values and 3 evaluations of the situation over time.

\begin{tabular}{|l|l|r|l|r|r|r|}
\cline { 2 - 8 } & $\begin{array}{l}\text { Weights of the importance of } \\
\text { the service }\end{array}$ & $\begin{array}{l}\text { Ideal } \\
\text { situation }\end{array}$ & $\begin{array}{l}\text { Penalization } \\
\text { criteria }\end{array}$ & $\begin{array}{l}\text { Situation at } \\
\text { moment 1 }\end{array}$ & $\begin{array}{l}\text { Situation at } \\
\text { moment 2 }\end{array}$ & $\begin{array}{l}\text { Situation at } \\
\text { moment 3 }\end{array}$ \\
\hline Char. 1 & $50 \%$ & 0.6 & penalizes $\neq$ & 0.3 & 0.5 & 0.7 \\
\hline Char. 2 & $20 \%$ & 0.8 & penalizes $<$ & 0.2 & 0.7 & 0.9 \\
\hline Char. 3 & $30 \%$ & 0.2 & penalizes $>$ & 0.5 & 0.1 & 0.1 \\
\hline
\end{tabular}

Table 3. Ideal values with penalization criteria, weights and situations at different moments

Using the data in Table 3, we obtain the index value for moment 1.

$$
\begin{aligned}
\left.\mathrm{I}_{\mathrm{g}}^{1} \text { (ideal, } \mathrm{x}\right)= & \frac{1}{3}(0,5 \cdot|0,6-0,3|+0,2 \cdot \max (0 ; 0,8-0,2)+0,3 \cdot \max (0 ; 0,5-0,2)) \\
& =\frac{1}{3}(0,5 \cdot 0,3+0,2 \cdot 0,6+0,3 \cdot 0,3)=0,12
\end{aligned}
$$

Next we obtain the index value for moment 2.

$$
\begin{aligned}
\mathrm{I}_{\mathrm{g}}^{2}(\text { ideal, } \mathrm{x})= & \frac{1}{3}(0,5 \cdot|0,6-0,5|+0,2 \cdot \operatorname{màxim}(0 ; 0,8-0,7)+0,3 \cdot \operatorname{màxim}(0 ; 0,1-0,2)) \\
& =\frac{1}{3}(0,5 \cdot 0,1+0,2 \cdot 0,1+0,3 \cdot 0)=0,02333 \ldots
\end{aligned}
$$

Finally, we obtain the index value for moment 3.

$$
\begin{aligned}
\mathrm{I}_{\mathrm{g}}^{3}(\text { ideal }, \mathrm{x})= & \frac{1}{3}(0,5 \cdot|0,6-0,7|+0,2 \cdot \operatorname{máxim}(0 ; 0,8-0,9)+0,3 \cdot \operatorname{màxim}(0 ; 0,1-0,2)) \\
& =\frac{1}{3}(0,5 \cdot 0,1+0,2 \cdot 0+0,3 \cdot 0)=0,01666 \ldots
\end{aligned}
$$

To demonstrate the potential of the new index, below is an example in a possible real-life situation that justifies the utility of the generalized index. Instead of characteristics, we will use the percentage of outsourcing as input values for the formula.

\section{Application of the generalized index of maximum and minimum level in the local public sector}

We will start with a town council that must provide services in each of the four groups of services presented in Section 2 of this work. Let's assume that when the government team begins its 4-year term, the ideal situation with the weights for each of the previous services were those shown in Table 4, understanding that an ideal situation in a group is $50 \%$, for example, is the same as saying that it is believed that $50 \%$ of the services in a group should be outsourced.

\begin{tabular}{|l|l|r|}
\cline { 2 - 3 } \multicolumn{1}{l|}{} & $\begin{array}{l}\text { Weights of the importance } \\
\text { of the service }\end{array}$ & Ideal situation \\
\hline $\begin{array}{l}\text { Mandatory services related to the maintenance of the } \\
\text { municipality and infrastructures }\end{array}$ & $20 \%$ & 0.50 \\
\hline Mandatory services related to global attention to people & $40 \%$ & 0.25 \\
\hline $\begin{array}{l}\text { Non-mandatory services related to the maintenance of } \\
\text { the municipality and infrastructures }\end{array}$ & $20 \%$ & 0.75 \\
\hline $\begin{array}{l}\text { Non-mandatory services related to global attention to } \\
\text { people }\end{array}$ & $20 \%$ & 0.5 \\
\hline
\end{tabular}

Table 4. Ideal values with weights of importance 
Let's also assume that the government team decides that the groups of services related to the maintenance of the municipality and infrastructures should be penalized for not reaching the desired objectives, while the groups related to global attention to people would be penalized for exceeding the set objectives. By reorganizing the groups of services, we can generate Table 5, which will give us a ranking in which the first $\mathrm{k}=0$ items are penalized for both an excess and a deficit, the $\mathrm{s}=2$ items are only penalized for a deficit and the last $\mathrm{m}=2$ items are penalized only for an excess, and thus it would make sense to use the generalized index of maximum and minimum level developed in the previous section.

\begin{tabular}{|l|r|r|r|}
\cline { 2 - 4 } \multicolumn{1}{l|}{} & $\begin{array}{l}\text { Weights of the } \\
\text { importance of the } \\
\text { service }\end{array}$ & $\begin{array}{l}\text { Ideal } \\
\text { situation }\end{array}$ & $\begin{array}{l}\text { Penalization } \\
\text { criteria }\end{array}$ \\
\hline $\begin{array}{l}\text { Mandatory services related to the maintenance of the } \\
\text { municipality and infrastructures }\end{array}$ & $20 \%$ & 0.50 & penalizes $<$ \\
\hline $\begin{array}{l}\text { Non-mandatory services related to the maintenance of } \\
\text { the municipality and infrastructures }\end{array}$ & $20 \%$ & 0.75 & penalizes $<$ \\
\hline Mandatory services related to global attention to people & $40 \%$ & 0.25 & penalizes $>$ \\
\hline $\begin{array}{l}\text { Non-mandatory services related to global attention to } \\
\text { people }\end{array}$ & $20 \%$ & 0.5 & penalizes $>$ \\
\hline
\end{tabular}

Table 5. Ideal values with penalization criteria and weights

Finally, let's suppose that the town council conducts an annual review in order to have an indicator of whether the actions to progress from the initial situation to the ideal situation have been appropriate. The values for the situation at the start of the legislature and at the end of each of the first four years of mandate are shown in Table 6.

\begin{tabular}{|c|c|c|c|c|c|}
\hline & $\begin{array}{l}\text { Initial } \\
\text { situation }\end{array}$ & $\begin{array}{l}\text { Final } \\
\text { situation } \\
\text { Year } 1\end{array}$ & $\begin{array}{l}\text { Final } \\
\text { situation } \\
\text { Year } 2\end{array}$ & $\begin{array}{l}\text { Final } \\
\text { situation } \\
\text { Year } 3\end{array}$ & $\begin{array}{l}\text { Final } \\
\text { situation } \\
\text { Year } 4\end{array}$ \\
\hline $\begin{array}{l}\text { Mandatory services related to the } \\
\text { maintenance of the municipality and } \\
\text { infrastructures }\end{array}$ & 0.25 & 0.25 & 0.25 & 0.25 & 0.75 \\
\hline $\begin{array}{l}\text { Non-mandatory services related to the } \\
\text { maintenance of the municipality and } \\
\text { infrastructures }\end{array}$ & 0.50 & 0.50 & 0.50 & 1 & 1 \\
\hline $\begin{array}{l}\text { Mandatory services related to global } \\
\text { attention to people }\end{array}$ & 0.75 & 0.75 & 0.5 & 0.5 & 0 \\
\hline $\begin{array}{l}\text { Non-mandatory services related to global } \\
\text { attention to people }\end{array}$ & 1 & 0.75 & 0.75 & 0.75 & 0.25 \\
\hline
\end{tabular}

Table 6. Values at different moments

Based on the data in Tables 5 and 6, we obtain the index value for the initial moment and the index values for the end of each year.

The fact that, year after year, the index tends towards zero shows that the actions performed by the town council in order to approach the ideal situation have been appropriate in terms of its strategy. If the governing party had published the ideal situation and the initial situation and had given details about the justification of the division of the weights, voters should have been satisfied with the work done in this regard during their mandate, since the trend towards the 0 value, in consonance with the fact that the index ultimately does become 0 , indicates that the town council has fulfilled $100 \%$ of the objectives established in this sense at the start of the term in office: 


$$
\begin{aligned}
& \mathrm{I}_{\mathrm{g}}^{0}(\text { ideal }, \mathrm{x})=\frac{1}{4}(0,2 \cdot \max (0 ; 0,5-0,25)+0,2 \cdot \max (0 ; 0,75-0,50)+ \\
& +0,4 \cdot \max (0 ; 0,75-0,25)+0,2 \cdot \max (0 ; 1-0,50)= \\
& =\frac{1}{4}(0,2 \cdot 0,25+0,2 \cdot 0,25+0,4 \cdot 0,5+0,2 \cdot 0,5)=0,1000 \\
& \left.\mathrm{I}_{\mathrm{g}}^{1} \text { (ideal, } \mathrm{x}\right)=\frac{1}{4}(0,2 \cdot \max (0 ; 0,5-0,25)+0,2 \cdot \max (0 ; 0,75-0,50)+ \\
& +0,4 \cdot \max (0 ; 0,75-0,25)+0,2 \cdot \max (0 ; 0,75-0,50)= \\
& =\frac{1}{4}(0,2 \cdot 0,25+0,2 \cdot 0,25+0,4 \cdot 0,5+0,2 \cdot 0,25)=0,0875 \\
& \mathrm{I}_{\mathrm{g}}^{2}(\text { ideal, } \mathrm{x})=\frac{1}{4}(0,2 \cdot \max (0 ; 0,5-0,25)+0,2 \cdot \max (0 ; 0,75-0,50)+ \\
& +0,4 \cdot \max (0 ; 0,5-0,25)+0,2 \cdot \max (0 ; 0,75-0,50)= \\
& =\frac{1}{4}(0,2 \cdot 0,25+0,2 \cdot 0,25+0,4 \cdot 0,25+0,2 \cdot 0,25)=0,0625 \\
& \mathrm{I}_{\mathrm{g}}^{3}(\text { ideal, } \mathrm{x})=\frac{1}{4}(0,2 \cdot \max (0 ; 0,5-0,25)+0,2 \cdot \max (0 ; 0,75-1)+ \\
& +0,4 \cdot \max (0 ; 0,5-0,25)+0,2 \cdot \max (0 ; 0,75-0,50) \\
& =\frac{1}{4}(0,2 \cdot 0,25+0,2 \cdot 0+0,4 \cdot 0,25+0,2 \cdot 0,25)=0,05 \\
& \mathrm{I}_{\mathrm{g}}^{4}(\text { ideal }, \mathrm{x})=\frac{1}{4}(0,2 \cdot \max (0 ; 0,5-0,75)+0,2 \cdot \max (0 ; 0,75-1)+ \\
& +0,4 \cdot \max (0 ; 0-0,25)+0,2 \cdot \max (0 ; 0,25-0,50)= \\
& =\frac{1}{4}(0,2 \cdot 0+0,2 \cdot 0+0,4 \cdot 0+0,2 \cdot 0)=0
\end{aligned}
$$

\section{Conclusions}

This work has presented a control tool to establish a measure that identifies whether a management team has improved or worsened the position of a public administration in an outsourcing strategy, with regard to certain established ideals. This measure must give the public administration a preliminary idea about the effectiveness of the actions taken in order to move closer to the ideal situation established as the ultimate objective of the outsourcing process. The work is a first approximation in this sense, as the tool used (a generalization of a tool used in works based on the fuzzy set theory) can be modified to include more extreme cases, such as penalties for moving too far away from a certain objective and doing nothing if we remain close to it. The incorporation of the perspective of the fuzzy set theory opens up enormous possibilities. The ability to use confidence intervals, triplets or Agnesi sets, to give just a few examples, opens up other new paths for future expansion. However, the merger of information is a new path to explore. Establishing mechanisms to find the ideal point based on several inputs or determining the weights of the importance of the service based on the opinions of several experts are possible examples in this direction.

This work has also provided a preliminary analysis classifying the different services that a local public administration must provide, and it allows us to perceive, through the defined mathematical analysis, which activities, services or groups of services, through a strategy defined by the managers, achieve adequate outsourcing levels with regard to the initial previsions. Likewise, it opens up a path to new mathematical formulas that, taking into account the strategic positioning of a local government, the correlation of its costs and the consequences of monitoring the services, among other variables, supports decision-making on internalizing or outsourcing certain services in town councils. 


\section{Declaration of Conflicting Interests}

The authors declared no potential conflicts of interest with respect to the research, authorship, and/or publication of this article.

\section{Funding}

The authors received no financial support for the research, authorship, and/or publication of this article.

\section{References}

Argyres, N. (1996). Evidence on the role of firm capabilities in vertical decisions. Strategic Management Journal, 17, 129-150. https://doi.org/10.1002/(SICI) 1097-0266(199602)17:2<129::AID-SMJ798>3.0.CO;2-H

Aristotle. De Interpretatione. (Trad. García Suárez, A.; Velarde Lombraña, J. (1977). Valencia: Cuadernos Teorema.

Black, M. (1937). Vagueness. An exercise in logical analysis. Philosophy of science, 4(4), 427-455. https://doi.org/10.1086/286476

Brown, T.L., \& Potoski, M. (2004). Managing the public service market. Public Administration Review, 64, 656-668. https://doi.org/10.1111/j.1540-6210.2004.00413.x

Brusca, I. (1997). Una nueva perspectiva de los informes financieros en contabilidad pública: Los indicadores de gestión. Revista de Contabilidad, 0(0), 27-56.

Christensen, T. (2006). Smart Policy? (The Oxford handbook of public policy). Oxford University Press, 77-102.

Corominas-Coll, D., Ferrer-Comalat, J.C., Linares-Mustarós, S., \& Bertran, X. (2017). A study of the strong Allee effect with fuzzy parameters for its application in economics. Kybernetes, 46(1), 191-206. https://doi.org/10.1108/K-06-2016-0154

De los Mozos, I. (2003). La gestión indirecta de los servicios públicos locales. Revista de Estudios de la Administración Local, 291, 751-768.

Espino, T.F., \& Padrón, V. (2004). ¿Qué actividades deberían externalizar las empresas? Una aproximación bajo la perspectiva de recursos y capacidades. Revista Investigaciones Europeas de Dirección y Economía de la Empresa, 10(1), 209-230.

Ferrer-Comalat, J.C., Linares-Mustarós, S., \& Corominas-Coll, D. (2016). A Model for optimal investment project choice using fuzzy probability. Economic Computation and Economic Cybernetics Studies and Research, 50, 187-203.

Ferrer-Comalat, J.C., Linares-Mustarós, S., \& Corominas-Coll, D. (2018). A Generalization of the Theory of Expertons. International Journal of Uncertainty, Fuzziness and Knowledge-Based Systems, 26(Suppl. 1), 121-139. https://doi.org/10.1142/S021848851840007X

Gil-Aluja, J. (1996). La gestión interactiva de los recursos bumanos en la incertidumbre. Madrid: Centro de Estudios Ramón Areces.

Gil-Aluja, J., \& Kaufmann, A. (1986). Introducción de la teoría de los subconjuntos borrosos a la gestión de la empresa. Santiago de Compostela, España: Editorial Milladoiro.

Gil-Lafuente, J. (2001). El 'Índice del Máximo y Mínimo Nivel’ en la Optimización del Fichaje de un Deportista. A: X Congreso Internacional A.E.D.E.M. Reggio Calabria, 439-443.

Girth A.M. et al. (2012). Outsourcing public service delivery: Management responses in noncompetitive markets. Public Administration Review, 72, 887-900. https://doi.org/10.1111/j.1540-6210.2012.02596.x

Johansson, T. (2008). Municipal contracting out: Governance choices, misalignment and performance in Swedish local government. Financial Accountability \& Management, 24, 243-264. https://doi.org/10.1111/j.14680408.2008.00452.x

Johnston, J.M., \& Girth, A.M. (2012). Government contracts and "managing the market" exploring the costs of strategic management responses to weak vendor competition. Administration \& Society, 44, 3-29.

https://doi.org/10.1177/0095399711417396 
Kaufmann, A., \& Gupta, M.M. (1988). Fuгzy Mathematical Models in Engineering and Management Science. The Netherlands: Elsevier Science Publisher.

Lazzari, L., Machado, E., \& Pérez, R. (2012). Los conjuntos borrosos: Una introducción. Cuadernos del CIMBAGE, 1, 1-25.

Linares-Mustarós, S., Ferrer-Comalat, J.C., \& Cassú-Serra, E. (2013). The assessment of cash flow forecasting. Kybernetes, 5, 720-735. https://doi.org/10.1108/K-03-2013-0060

Linares-Mustarós, S., Merigó, J.M., \& Ferrer-Comalat, J.C. (2015). Processing extreme values in sales forecasting. Cybernetics and Systems, 46 (3-4), 207-222. https://doi.org/10.1080/01969722.2015.1012891

Linares-Mustarós, S., Ferrer-Comalat, J.C., Corominas-Coll, D., \& Merigó, J.M. (2019). The ordered weighted average in the theory of expertons. International Journal of Intelligent Systems, 34(3), 345-365.

https://doi.org/10.1002/int.22055

Lodge, M., \& Hood, C. (2012). Into an age of multiple austerities? Public management and public service bargains across OECD countries. Governance: An International Journal of Policy, Administration and Institutions, 25(1), 79-101.

Lukasiewicz, J. (1920). O logice trójwartościowej. Ruch Filozoficzny, 5, 170-171. (Trad. en Deaño, A. (1970). Estudios de lógica y Filosofia. Revista de Occidente, Madrid).

Mas, D., \& Vilalta, M. (2011). El gasto no obligatorio de los municipios españoles (2004-2007). Institut d'Economia de Barcelona.

Mas, J. (2000). Gestión privada de servicios públicos: La externalización (outsourcing) en la administración pública. $V$ Congreso Internacional del CLAD.

Mas, J. (2004) Un nuevo modelo de externalización (tercerización/outsourcing) en la administración pública. IX Congreso Internacional del CLAD.

Montesinos, V., \& Gimeno, A. (1998). Contabilidad y Control en el marco de La Nueva Gestión Pública. IV Jornada de Trabajo sobre Contabilidad de Costes y Gestión, ASEPUC, 145-172.

Mouzelis, N.P. (1989). Organización y burocracia. Barcelona: Ed. Península.

Russell, B. (1923). Vagueness. The Australasian Journal of Psychology and Philosophy, 1(2), 84-92. https://doi.org/10.1080/00048402308540623

Santolaria, J. (2004) La externalización a través del sector privado: Evaluación y participación del ciudadano. IX Congreso Internacional del CLAD.

Savas, ES. (2000). Privatization and Public-Private Partnerships. New York: Seven Bridges Press.

Sosa, F. (1992). La gestión de los servicios públicos locales. Madrid: Ed. Civitas.

Trillas, E., Alsina, C., \& Terricabras, J. (1995). Introducción a la lógica borrosa. Barcelona: Ariel.

Van Slyke, D.M. (2003). The mythology of privatization in contracting for social services. Public Administration Review, 63(3), 277-296. https://doi.org/10.1111/1540-6210.00291

Viñas, J. (2012) Causas para externalizar servicios en la Administración pública. Revista Presupuesto y Gasto Público, 66, 167-182.

White, R., \& James, B. (2000). Manual del outsourcing. Barcelona: Ediciones Gestión 2000.

Zadeh, L.A. (1965). Fuzzy sets. Information and Control, 8, 338-353. https://doi.org/10.1016/S0019-9958(65)90241-X

Intangible Capital, 2019 (www.intangiblecapital.org)

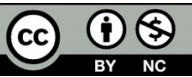

Article's contents are provided on an Attribution-Non Commercial 4.0 Creative commons International License. Readers are allowed to copy, distribute and communicate article's contents, provided the author's and Intangible Capital's names are included. It must not be used for commercial purposes. To see the complete license contents, please visit https://creativecommons.org/licenses/by-nc/4.0/. 